\title{
PILKADA DAN KESEJAHTERAAN \\ MASYARAKAT: STUDI KEBIJAKAN \\ PEMBANGUNAN DI PROVINSI JAMBI PASCA PEMILIHAN GUBERNUR 2015
}

\section{Pahrudin HM}

Universitas Nurdin Hamzah

Email: pahrudinhm9@gmail.com

\section{Firdaus}

Universitas Nurdin Hamzah

Email: firdaussudirmanz@gmail.com

\begin{abstract}
Islam has a political concept that functions to realize synergistic welfare between the interests of the world and the hereafter. In Islam, the government must take a significant role in regulating people's lives based on the principles of the Qur'an and Sunnah. In the Indonesian context, regional autonomy provides wider space for regions to develop their territories so that people's welfare can be realized. Various studies show that local governments play a major role in efforts to improve people's welfare through their development policies. Jambi Province is a region that has held several regional elections, one of which was in 2015 when Zumi Zola and Fachrori Umar were elected as governor and deputy governor. Efforts to build Jambi with its various resources are carried out by the government through its vision and mission known as TUNTAS and aimed at improving the welfare of the community in 2015-2021. Based on this research, it is known that poverty is still a major problem that must be resolved by the Jambi Provincial Government. In addition, unemployment and development inequality between regions in Jambi Province are also problems that the government should pay attention to through innovative-solution policies in the future.
\end{abstract}

Keywords: Islam, autonomy, regional election, policy, welfare

\begin{abstract}
Abstrak
Islam memiliki konsep politik yang berfungsi untuk merealisasikan kesejahteraan yang sinergis antara kepentingan kehidupan dunia dan akhirat. Pemerintah dalam Islam harus mengambil peran yang signifikan
\end{abstract}


dalam mengatur kehidupan masyarakat berdasarkan prinsip-prinsip alQur'an dan Sunnah. Dalam konteks Indonesia, otonomi daerah memberi ruang yang lebih luas bagi daerah untuk membangun wilayahnya agar kesejahteraan masyarakat dapat terwujud. Upaya membangun diwujudkan melalui kebijakan-kebijakan pembangunan pemerintah daerah yang diusung kepala daerah yang terpilih melalui pilkada. Beragam studi memperlihatkan bahwa pemerintah daerah berperan besar dalam upaya meningkatkan kesejahteraan masyarakat melalui kebijakankebijakan pembangunannya. Provinsi Jambi merupakan wilayah yang telah beberapa kali menyelenggarakan pilkada, salah satunya tahun 2015 dengan terpilihnya Zumi Zola dan Fachrori Umar sebagai gubernur dan wakil gubernur. Upaya membangun Jambi dengan beragam sumberdayanya dilakukan pemerintah melalui visi misinya yang dikenal dengan TUNTAS dan ditujukan untuk meningkatkan kesejahteraan masyarakat tahun 2015-2021. Berdasarkan penelitian ini diketahui bahwa kemiskinan masih menjadi problem utama yang harus dicarikan solusinya oleh Pemerintah Provinsi Jambi. Di samping itu, pengangguran dan ketimpangan pembangunan antar wilayah di Provinsi Jambi juga menjadi problem-problem yang harus menjadi perhatian pemerintah melalui kebijakan-kebijakan inovatif-solutif di masa-masa mendatang.

Kata Kunci: Islam, otonomi daerah, pilkada, kebijakan, kesejahteraan

\section{Pendahuluan}

Gerakan reformasi yang dimotori mahasiswa pada tahun 1998 banyak mengubah wajah Indonesia, salah satunya perubahan sistem pemerintahan dari sentralistik menjadi desentralisasi. Konsekuensi logis dari perubahan tersebut membuat urusanurusan rakyat yang sebelumnya menjadi tanggung jawab pemerintah pusat sepenuhnya, menjadi urusan pemerintah daerah dalam kerangka desentralisasi. ${ }^{1}$ Tertujunya pilihan terhadap sistem yang juga dikenal sebagai otonomi daerah ini tentu tidak semata agar berbeda dengan langkah yang dilakukan pemerintah Orde Baru yang digantikan. Dipilihnya desentralisasi karena berdasarkan pertimbangan-pertimbangan rasional yang dilakukan oleh segenap pemimpin bangsa ini. Desentralisasi diyakini sebagai solusi efektif

1 Abdul Halim. Politik Lokal: Pola, Aktor, dan Alur Dramatikalnya. (Yogyakarta: Lembaga Pengkajian Pembangunan Bangsa (LP2B), 2014). 7. 
untuk mengatasi beragam problem yang muncul di kala Indonesia berada di masa sentralisasi. Merujuk pendapat Stoker ${ }^{2}$ serta Bird dan Vaillancourt ${ }^{3}$, desentralisasi dipilih sebagai sistem pemerintahan karena memiliki beberapa keunggulan. Pertama, kebijakan desentralisasi yang menjadi dasar pengelolaan daerah pasca reformasi menjanjikan efisiensi ekonomi, efektivitas biaya program, akuntabilitas, peningkatan mobilisasi sumber daya, berkurangnya tingkat kesenjangan (disparitas), peningkatan partisipasi politik, serta penguatan demokrasi dan stabilitas politik. Kedua, melalui desentralisasi, pemerintah lokal dinilai memiliki pengetahuan (knowledge) yang lebih baik tentang kebutuhan (needs) dan preferensi (preferences) warga masyarakatnya, maka proses pembangunan dalam model kebijakan desentralisasi seharusnya menjadi lebih efisien daripada model kebijakan sentralisasi dalam kerangka meningkatkan kesejahteraan masyarakat lokal.

Pilihan terhadap sistem desentralisasi juga memiliki konsekuensi lain berupa pelaksanaan pemilihan umum di tingkat daerah (Pilkada) di berbagai wilayah di Indonesia, baik di tingkat provinsi maupun kabupaten/kota. Gelaran pilkada merupakan hasil dari demokratisasi yang semakin menampakkan signifikansinya pasca runtuhnya Orde Baru melalui gerakan reformasi 1998. Orde Baru yang sentralistik tidak mengenal Pilkada, karena kepala daerah dipilih dan ditetapkan dalam rapat legislatif di kantor DPRD. Pilkada memungkinkan dapat dilangsungkan karena Indonesia di era reformasi sudah menganut sistem desentralisasi yang mewujudkan diri dalam format otonomi daerah. Dengan gelaran pilkada, harapannya akan menghasilkan pemimpin yang betul-betul menguasai setiap aspek mengenai daerah yang akan dipimpinnya. Ini tentu berbeda dengan di era sentralistik karena kepala daerah lebih merupakan 'titipan' pemerintah pusat yang seringkali tidak begitu mengenal daerahnya.

2 Gerry Stoker. The Politics of Local Government. (London: The Macmillan Press Ltd, 1991). 5.

${ }^{3}$ R. Bird \& F. Vaillancourt. Fiscal Decentralization in Developing Countries. (Cambridge University Press, United Kingdom, 1998). 8. 
Pemimpin yang lahir dari sistem pilkada diharapkan akan melakukan beragam cara membangun daerah yang dipimpinnya.

Besarnya harapan publik terhadap Pilkada ditunjukkan dari data-data partisipasi politik yang dikeluarkan KPU dari tahun ke tahun. Data partisipasi publik pada pemilu nasional 2014 sebesar 69,58 persen dan 2019 sebesar 81 persen, Pemilihan Gubernur Jawa Timur 2018 sebesar 69,55 persen, Pemilihan Gubernur Jawa Tengah 2018 sebesar 73,2 persen, dan Pemilihan Gubernur Jambi 2015 sebesar 65,66 persen. Hal serupa juga mengemuka dalam data Pilkada pada tingkat kabupaten/kota sebagai wujud otonomi daerah secara politik yang tetap memperlihatkan tingginya partisipasi politik rakyat. Data KPU Kabupaten Tebo, misalnya, mencatat angka 75,4 persen partisipasi politik masyarakat dalam Pilkada 2017, sedangkan di 2 kabupaten lainnya sebanyak 70 persen (Sarolangun) dan 65 persen (Muaro Jambi). Data ini sekaligus mengonfirmasi penguatan demokrasi dan stabilitas politik yang menjadi alasan kenapa desentralisasi yang kemudian melahirkan otonomi daerah secara politik ini dipilih pasca reformasi.

Data-data di atas menunjukkan bahwa masyarakat sangat antusias mengambil bagian dalam gelaran pemilu, terlepas dari beragam faktor yang menyebabkannya. Tinggal sekarang bagaimana potensi partisipasi, demokrasi dan stabilitas politik yang tinggi ini mampu diolah dengan baik oleh pemimpin terpilih. Potensi-potensi tersebut harus dijadikan trigger bagi pemimpin terpilih untuk menghasilkan kebijakan-kebijakan publik yang inovatif-solutif agar kesejahteraan yang sudah digariskan konstitusi dapat segera diwujudkan. Kebijakan-kebijakan publik yang mampu mengatasi masalah-masalah utama negeri ini, seperti kemiskinan $(9,41 \%)$ dan di beberapa daerah ada yang lebih dan cenderung mendekati angka tersebut. ${ }^{4}$

${ }^{4}$ Badan Pusat Statistik. Provinsi Jambi Dalam Angka 2019. (Jambi: Badan Pusat Statistik Provinsi Jambi, 2019). 
Dari sinilah logika pemilihan otonomi daerah sebagai sistem politik Indonesia pasca Orde Baru menemukan signifikansinya. Ada korelasi yang segaris lurus antara Pilkada dengan kesejahteraan. Beragam problem sosial, terutama kemiskinan, seharusnya akan dapat diatasi dengan pelaksanaan otonomi daerah yang salah satunya diwujudkan dalam bentuk pilkada. ${ }^{5}$ Karena pilkada akan menghasilkan pemimpin yang memahami betul potensi dan problem daerahnya. Dengan demikian, pemimpin daerah diharapkan akan menghasilkan beragam kebijakan publik yang inovatif-solutif bagi problem sosial masyarakat daerah. ${ }^{6}$ Implementasi dari kebijakan inovatif-solutif tersebut jika dijalankan dengan baik, maka kesejahteraan yang sudah menjadi visi negara ini akan dapat tercapai dengan sukses. Karenanya, pilkada dengan pemimpin daerah yang dihasilkannya akan menjadi problem-solver bagi masalah-masalah sosial masyarakat, bukan malah sebaliknya menjadi problem-maker karena serangkaian perilaku koruptif yang dilakukannya.

Beragam studi memperlihatkan besarnya peranan pemerintah daerah dalam upaya mewujudkan kesejahteraan masyarakat, di antaranya kajian yang dilakukan oleh Kisman and Tasar $^{7}$ dan Witkowski and Kiba-Janiak ${ }^{8}$. Kedua penelitian ini memperlihatkan besarnya peranan pemerintah daerah (di Turki dan Polandia) dalam upaya mengatasi problem-problem sosial yang dihadapi masyarakat. Studi-studi ini juga menegaskan bahwa pemerintah daerah lebih dapat meningkatkan kesejahteraan

5 Pahrudin HM. 'The role of the Merangin regency government through welfare policy in the globalization era'. The Journal of Society and Media 2019, Vol. 3(2) 216-236. DOI:10.26740/jsm.v3n2.p216-236.

${ }^{6}$ Riant Nugroho. Public Policy: Dinamika Kebijakan Publik, Analisis Kebijakan Publik, dan Manajemen Politik Kebijakan Publik. (Jakarta: PT. Elex Media Komputindo, 2018). 10.

7 Kisman, Z. A. and Tasar, I. (2014). 'The key element of local development' Procedia Economics and Finance, 15, pp. 1689-1696, 2014. https://doi.org/10.1016/S2212-5671(14)00642-X.

${ }^{8}$ Wikowski, J. and Kiba-Janiak, M. (2014). 'The role of local governments inthe development city logistics' Procedia-Social and Behavioral Sciences, 125, p. 373385,2014. https://doi.org/10.1016/j.sbspro.2014.01.1481. 
masyarakat, dibandingkan ketika pemerintahan masih berada pada sistem sentralisasi. Di samping itu, studi yang dilakukan oleh Nakai etc. ${ }^{9}$, Sharma ${ }^{10}$ dan Brillo ${ }^{11}$ juga memperlihatkan bahwa peranan yang dimainkan pemerintah daerah dengan berkolaborasi dengan beberapa stakeholders mampu meningkatkan derajat hidup masyarakat.

Berdasarkan studi yang dilakukan oleh HM (2019), Kisman and Tasar (2014), Witkowski and Kiba-Janiak (2014), Nak-ai etc. (2018), Sharma (2015) dan Brillo (2017) dapat ditarik kesimpulan bahwa terwujud atau tidaknya kesejahteraan masyarakat sangat tergantung dengan upaya yang dilakukan pemerintah daerah. Hal ini sejalan dengan Undang-Undang Nomor 23 Tahun 2014 tentang Otonomi Daerah yang didalamnya menyebutkan bahwa pemerintah daerah dalam melaksanakan otonomi daerah wajib memenuhi kebutuhan daerahnya sesuai dengan anggaran yang telah ditetapkan dengan tujuan untuk meningkatkan kesejahteraan masyarakatnya. Dalam menyelenggarakan otonomi, daerah mempunyai kewajiban diantaranya yaitu: meningkatkan kualitas dan kehidupan masyarakat, mengembangkan kehidupan demokrasi, mewujudkan keadilan dan pemerataan, meningkatkan pelayanan dasar pendidikan, menyediakan fasilitas pelayanan kesehatan, dan menyediakan fasilitas sosial dan fasilitas umum yang layak. Dengan demikian, secara teoritis, sebagaimana disebutkan sebelumnya bahwa model kebijakan desentralisasi

9 Nak-ai, W. etc. (2018). 'Community public policy process for solving cadmium contamination problems in the environment: a case study of Mae Sod District, Tak Province. Kasetsart Journal of Social Sciences 39 (2018) 59-66. https://doi.org/10.1016/j.kjss.2017.11.006.

10 Sharma, C. K. (2015). 'Reimagining federalism in india: exploring the frontiers of collaborative federal architecture'. Asia-Pacific Social Science Review 15 (1) 2015, pp. 1-25. Retrieved from http://apssr.com/volume-15-no1 /reimagining-federalism-in-india-exploring-the-frontiers-of-collaborativefederal-architecture/.

11 Brillo, B. B. C. (2017). 'The politics of lake governance: Sampaloc Lake, Pandin Lake, and Tadlac Lake of the Laguna de Bay Region, Philippines'. AsiaPacific Social Science Review (2017) 17(1): 66-79. Retrieved from https://papers.ssrn.com/sol3/papers.cfm?abstract_id=2979439. 
seharusnya mampu membawa tingkat kesejahteraan yang lebih baik dibandingkan bila dengan sistem sentralisasi.

Atas dasar demikian, menarik untuk mencermati kondisi kesejahteraan masyarakat Provinsi Jambi dalam kurun waktu 5 tahun terakhir pasca 21 tahun reformasi digulirkan. Sebagaimana diketahui bahwa Provinsi Jambi merupakan salah satu wilayah strategis yang berada di jantung Pulau Sumatera dengan sumberdaya alam (karet dan kelapa sawit) sebagai andalan utama perekonomiannya. Luas wilayah Provinsi Jambi adalah sebesar $53.435,92 \mathrm{~km}^{2}$ yang terdiri dari daratan seluas $48.989,98 \mathrm{~km}^{2}$ dan lautan 4.445,94 $\mathrm{km}^{2}$ dengan panjang garis pantai $223,025 \mathrm{~km}$ serta jumlah penduduk sebanyak 3.570.272 jiwa dan tingkat kepadatan rata-rata sebesar $71,18 \mathrm{jiwa} / \mathrm{km}^{2}$ (BPS, 2019). Pasca reformasi, silih berganti terpilih gubernur yang memimpin wilayah ini berupaya mewujudkan kesejahteraan masyarakat melalui beragam program kerjanya. Pada kurun waktu 5 tahun terakhir pasca reformasi, terpilih Zumi Zola dan Fachrori Umar untuk memimpin Provinsi Jambi 2015-2021 melalui pemilihan gubernur tahun 2015. Berdasarkan penetapan KPU Provinsi Jambi tanggal 18 Desember 2015, Zumi Zola Zulkifli dan Fachrori Umar memenangi Pemilihan Gubernur Jambi 2015 dengan perolehan suara 956.497 suara $(60,25 \%)$, sedangkan pesaingnya, Hasan Basri Agus dan Edi Purwanto memperoleh 639.075 suara (39,75\%). Zumi Zola Zulkifli dan Fachrori Umar didukung oleh Partai Nasdem, PAN, PKB, Hanura dan PBB, sedangkan Hasan Basri Agus dan Edi Purwanto didukung oleh Partai Demokrat, PDIPerjuangan, PKS, dan Partai Gerindra. Hanya saja, oleh karena Zumi Zola kemudian tersangkut kasus korupsi oleh KPK, sehingga sejak 10 April 2018 posisinya sebagai Gubernur Jambi digantikan oleh Fachrori Umar. 


\section{Pembahasan}

\section{Kebijakan Pembangunan Provinsi Jambi 2016-2021}

Sebagaimana diketahui bahwa terdapat korelasi yang segaris lurus antara Pilkada dengan kesejahteraan masyarakat. Pilkada merupakan mekanisme demokratis yang dihasilkan dari reformasi untuk memilih pemimpin lokal/daerah agar kemudian dapat menghasilkan kebijakan-kebijakan dalam upaya menyejahteraan masyarakat. Hal ini sejalan dengan kebijakan publik yang dipahami sebagai tindakan yang dilakukan pemerintah dalam upaya mengatasi masalah yang ada dalam masyarakat. ${ }^{12}$

Apalagi kemudian dikaitkan dengan Islam sebagai agama paripurna yang memiliki seperangkat tujuan dan nilai yang mengatur seluruh aspek kehidupan, termasuk di dalamnya aspek sosial, ekonomi dan politik. Selain sebagai ajaran normatif, Islam juga berfungsi sebagai pandangan hidup (World View) bagi segenap para penganutnya. Dari hal ini, tentu saja Islam juga memiliki konsep ketatanegaraan yang berfungsi untuk merealisasikan kesejahteran yang sinergis antara kepentingan dunia dan akhirat. ${ }^{13}$

Upaya mewujudkan cita-cita luhur terkait kehidupan masyarakat yang sejahtera tersebut tentu tidak dapat dilepaskan dari peranan pemerintah melalui serangkaian kebijakan yang menjadi tanggung jawabnya. Tanggung jawab pemerintah dalam persepektif Islam memiliki fleksibilitas yang luas didasarkan pada premis bahwa Islam bertujuan untuk menyejahterakan umum masyarakat. Karenanya, dalam negara persepektif Islam dapat

12 Pahrudin HM (2020), Globalisasi dan Kebijakan Publik: Kajian Seputar Peranan Pemerintah Mewujudkan Kesejabteraan di Tengab Dunia Tak Bersekat, (Jakarta: Kencana Prenada Media Group), hlm. 98.

13 Arsyad Sobby Kesuma, 'Islam dan politik pemerintahan (pemikiran politik Muhammad Husein Haikal)'. Analisis, Volume XIII, Nomor 2, Desember 2013. Retrieved from https://media.neliti.com/media/publications/57574-IDislam-dan-politik-pemerintahan-pemikiran.pdf. 
mendefinisikan apapun fungsinya dalam mencapai sasaran tersebut. $^{14}$

Berdasarkan ketentuan Islam, fungsi negara dapat diklasifikasikan dalam tiga kategori. $^{15}$ Pertama, fungsi yang diamanahkan syari'at secara permanen meliputi pertahanan, hukum dan ketertiban, keadilan, pemenuhan kebutuhan, dakwah, amar makruf nahi munkar, administrasi sipil, pemenuhan kewajibankewajiban sosial. Kedua, fungsi turunan syari'ah yang berbasis ijtihad sesuai kondisi sosial dan ekonomi pada waktu tertentu, meliputi perlindungan lingkungan, penyediaan sarana kepentingan umum, penelitian, pengumpulan modal dan pembangunan ekonomi, penyediaan subsidi pada kegiatan swasta tertentu, dan pembelanjaan yang diperlukan untuk stabilitas kebijakan. Ketiga, fungsi yang diamanahkan secara kontekstual berdasarkan proses musyawarah (syura), meliputi semua kegiatan yang diamanahkan masyarakat kepada sebuah proses syura. Prinsip yang ketiga inilah yang terbuka dan berbeda-beda di setiap negara tergantung konteks dari masing-masing wilayah yang ditempati oleh orangorang Islam, seperti Indonesia dengan sistem demokrasinya.

Pada konteks ini, Pilkada merupakan mekanisme demokratis untuk menghasilkan pemimpin lokal yang dapat menjalankan amanahnya menyejahterakan masyarakat melalui kebijakankebijakan pembangunannya. Secara substansial, Pemilihan Gubernur tahun 2015 merupakan proses politik paling baru pasca reformasi sekaligus untuk pertama kalinya seorang petahana gagal memenangi kontestasi di Provinsi Jambi. Seorang Hasan Basri Agus sebagai gubernur harus mengakui keunggulan rivalnya dengan perolehan suara yang terpaut jauh, Zumi Zola, dalam kontestasi politik yang hanya diikuti oleh dua pasangan ini. Berbekal dukungan suara rakyat 60,25 persen, Zumi Zola kemudian menjadi gubernur termuda yang pernah memimpin

14 Ismail Nawawi, Ekonomi Islam; Persepektif Konsep, Model, Paradigma,Teori dan Aspek Hukum, (Surabaya: Vira Jaya Multi Press, 2008). 283.

15 Indra Hidayatullah, 'Peran pemerintah di bidang perekonomian dalam Islam'. DINAR, Vol. 1 No. 2 Januari 2015. Hlm. 79-80. 
provinsi yang terletak di jantung pulau Sumatera dan kaya dengan beragam potensi sumberdaya alam ini. Pengalaman menjadi Bupati Tanjung Jabung Timur (2011-2015) dengan dukungan mayoritas rakyat menjadi bekal yang sangat berharga bagi Zumi Zola untuk memimpin wilayah menjadikan karet dan kelapa sawit sebagai komoditas unggulan ini.

Setelah resmi menjadi Gubernur dan Wakil Gubernur Jambi pada tanggal 12 Februari 2016, Zumi Zola dan Fachrori Umar kemudian mulai mengelola wilayah ini melalui kebijakan-kebijakan pembangunannya. Sebagaimana yang disampaikannya saat kampanye, Zumi Zola dan Fachrori Umar mendasarkan programprogram pembangunannya di Provinsi Jambi pada visi dan misi yang dikenal dengan Jambi Tuntas 2021 (Tertib, Unggul, Nyaman, Tangguh, Adil dan Sejahtera).

Dalam rangka mewujudkan visi tersebut, ditetapkan 6 (enam) Misi Pembangunan Provinsi Jambi Tahun 2016 - 2021, sebagai berikut: Meningkatkan tata kelola pemerintahan daerah yang bersih, transparan, akuntabel dan partisipatif yang berorientasi pada pelayanan publik, yaitu menerapkan prinsip prinsip tata kelola pemerintahan yang baik, meningkatkan kuantitas aparatur pemerintahan yang profesional, berkinerja tinggi dan berorientasi melayani masyarakat. Meningkatkan kualitas sumber daya manusia yang sehat, terdidik, berbudaya, agamis dan berkesetaraan gender, yaitu membangun sumber daya manusia yang berdaya saing, ditandai oleh penduduk laki-laki dan perempuan yang memiliki tingkat pendidikan dan derajat masyarakat kesehatan yang lebih baik serta adil dalam kerangka masyarakat yang berbudaya dan agamis. Menjaga situasi daerah yang kondusif, toleransi antar umat beragama dan kesadaran hukum masyarakat, yaitu melakukan langkah-langkah antisipasi dan pencegahan terhadap potensi konflik yang muncul dengan menerapkan kepastian hukum sehingga suasana aman, tenteram dan kondusif. Meningkatkan daya saing daerah melalui optimalisasi pembangunan ekonomi kerakyatan yang didukung oleh penerapan 
Ilmu Pengetahuan, teknologi, dan inovasi (IPTEKIN) berwawasan lingkungan, yaitu meningkatkan nilai tambah produk-produk unggulan daerah dengan memanfaatkan IPTEKIN yang ramah lingkungan. Meningkatkan aksesibilitas dan kualitas infrastruktur umum, pengelolaan energi dan sumber daya alam yang berkeadilan dan berkelanjutan, yaitu meningkatkan aksesibilitas dan kualitas infrastruktur dasar serta mengoptimalkan potensi sumber energi terbarukan untuk pemerataan akses energi wilayah sehingga dapat meningkatkan produktivitas dan mobilitas penduduk antar wilayah. Meningkatkan kualitas kehidupan masyarakat, yaitu meningkatkan aksesibilitas masyarakat miskin terhadap kehidupan yang lebih baik.

Berdasarkan rumusan Visi dan Misi dan mengacu serta selaras dengan arahan tehnis operasional dokumen Rencana Pembangunan Jangka Menengah (RPJM) Nasional Tahun 20142019 dan Rencana Pembangunan Jangka Panjang (RPJP) Provinsi Jambi Tahun 2005 -2025, maka kedepan tujuan pembangunan daerah untuk penyelenggaraan pemerintahan dan pelaksanaan pembangunan 5 (lima) tahun ke depan adalah : Mewujudkan Jambi dengan infrastruktur pelayanan umum yang berkualitas dan ketersediaan yang lebih baik. Mewujudkan kualitas pendidikan, kesehatan dan kondisi masyarakat Jambi yang berkehidupan beragama dan berbudaya. Mewujudkan Jambi dengan struktur ekonomi yang kokoh dengan berbasis pada ilmu pengetahuan dan teknologi. Menciptakan pengelolaan sumberdaya alam secara terpadu dengan mengedepankan penataan ruang dan lingkungan. Mewujudkan kualitas kinerja birokrasi pemerintah secara profesional dalam memenuhi kepentingan umum.

Kebijakan pembangunan Provinsi Jambi difokuskan kepada upaya peningkatan kesejahteraan masyarakat dan merupakan turunan dari kebijakan pembangunan Nasional dengan mempertimbangkan keunggulan daerah dan kearifan lokal masyarakat. Arah kebijakan pembangunan Provinsi Jambi lebih diprioritaskan pada sinergitas antara kebijakan nasional dan 
Provinsi Jambi dengan lebih mengutamakan penanganan pada permasalahan pembangunan dan isu-isu strategis daerah. Rencana Pembangunan Jangka Panjang Daerah Provinsi Jambi 2005 - 2025 juga menjadi rujukan untuk mewujudkan pembangunan daerah yang merata dan berkeadilan dengan mengurangi kesenjangan sosial ekonomi dan keberpihakan kepada daerah tertinggal dan penduduk miskin. Di samping itu, juga harus dilakukan upaya meningkatkan pelayanan sosial ekonomi dan kesetaraan gender bagi masyarakat. Untuk itu, dalam menyelenggarakan pembangunan daerah di Provinsi Jambi lebih diarahkan pada :

1) Pembangunan ekonomi daerah yang berkualitas didasarkan kepada pengembangan agribisnis dan agroindustri unggulan yang ditumbuhkembangkan sesuai potensi sumberdaya daerah yang dimiliki.

2) Pembangunan infrastruktur yang berkualitas dan merata difokuskan pada upaya mempererat keterkaitan ruang antar kawasan, percepatan pembangunan kawasan ekonomi strategis cepat tumbuh dan pemerataan ketersediaan infrastruktur dasar berkualitas di setiap daerah.

3) Peningkatan sumberdaya manusia yang berkualitas difokuskan pada pembangunan pendidikan yang berorientasi pada peningkatan kompetensi yang sesuai kebutuhan dan pembangunan kesehatan yang berorientasi pada penyiapan manusia Jambi yang sehat dan dapat hidup layak.

4) Peningkatan tata kelola pemerintahan yang baik dan bersih yang dapat memberikan pelayanan publik yang prima dan memberi jaminan kepastian hukum.

5) Peningkatan pengelolaan sumberdaya alam yang berkualitas sehingga menjamin ketersediaan sumberdaya alam dan kelestarian lingkungan hidup sekarang dan mendatang.

Selain itu, pembangunan di Provinsi Jambi juga diarahkan sesuai dengan potensi dan fungsi ruangnya. Oleh karena itu, sebagaimana telah diarahkan dalam RTRW Provinsi Jambi Tahun 2013-2033, penyelenggaraan pembangunan kewilayahan di Provinsi 
Jambi lebih diarahkan pada : 1) Mengalokasikan penggunaan ruang di Provinsi Jambi (pola ruang) dengan menyerasikan kegiatan antar sektor dengan kebutuhan ruang dan potensi sumberdaya alam yang berasaskan kelestarian lingkungan menuju pembangunan yang berkelanjutan; 2) Pengembangan sarana prasarana yang diarahkan pada upaya mempererat keterkaitan spasial antar kawasan (struktur ruang); 3) Mengakselerasi pertumbuhan wilayah yang potensial untuk tumbuh, menjaga pertumbuhan pada kawasan strategis dan cepat tumbuh dengan tetap memperhatikan aspek keseimbangan pertumbuhan wilayah dalam satuan ruang; dan 4) Mendorong pengembangan wilayah untuk setiap kabupaten/kota di Provinsi Jambi berdasarkan pertimbangan sektor andalan, sektor potensial/unggulan dan kendala pengembangan yang ada.

\section{Kesejahteraan Masyarakat Provinsi Jambi 5 Tahun Terakhir}

Secara konseptual, muara (outcome) dari kebijakan-kebijakan yang dijalankan oleh pemerintah adalah kesejahteraan masyarakat. Hal ini karena kehadiran negara/pemerintah memang ditujukan untuk menghadirkan kesejahteraan rakyat. Pembicaraan mengenai kesejahteraan erat kaitannya dengan kemiskinan. Hal ini karena kemiskinan merupakan implikasi dari tidak terwujudnya kesejahteraan. Kemiskinan merupakan permasalahan bangsa yang mendesak dan memerlukan langkah-langkah penanganan dan pendekatan yang sistematik, terpadu dan menyeluruh melalui kebijakan pembangunan yang inovatif, inklusif, berkeadilan, dan berkelanjutan untuk mewujudkan kehidupan yang bermartabat. Kemiskinan dapat dimaknai sebagai kekurangan barang-barang dan pelayanan-pelayanan yang dibutuhkan untuk mencapai suatu standar hidup yang layak dan juga dipahami sebagai ketidakmampuan seseorang untuk memperoleh barang-barang dan pelayanan-pelayanan yang memadai untuk memenuhi kebutuhan sosial yang terbatas. ${ }^{16}$ Sementara menurut Soetomo ${ }^{17}$, keadaan

${ }^{16}$ Bagong Suyanto. Perangkap Kemiskinan, Problem dan Strategi Pengentasannya dalam Pembangunan Desa. (Yogyakarta: Aditya Media, 1996). 1. 
kemiskinan yang telah berlangsung lama dalam suatu komunitas memunculkan perilaku sikap fatalistik, ingroup orientation dan ketergantungan. Sedangkan Robert Chamber $^{18}$ menyebutkan bahwa jaring atau perangkap kemiskinan memperparah kondisi kemiskinan yang mengidentifikasikan diri dalam bentuk kelemahan fisik, isolasi, kerentanan, dan ketidakberdayaan. Dari beberapa pengertian tentang kemiskinan, dapat diketahui bahwa kemiskinan merupakan fenomena yang kompleks, bersifat multi dimensional mencakup dimensi psikologi, sosial-kultural, ekonomi, fisik, politik, kelembagaan, dan bersifat unik untuk setiap daerah karena memiliki karakteristik yang cukup bervariatif.

Permasalahan kemiskinan yang belum terselesaikan melalui serangkaian kebijakan dalam bentuk program-program penanggulangan kemiskinan yang diinisiasi oleh Pemerintah Daerah, akan menghambat peningkatan kesejahteraan. Secara umum, permasalahan kemiskinan yang terjadi di wilayah Indonesia beberapa diantaranya disebabkan oleh rendahnya pendidikan, tingginya angka pengangguran, sedikitnya lapangan pekerjaan, kurangnya kreatifitas (mental miskin), kemiskinan cultural (turunan), dan lemahnya akses atas aset-aset ekonomi. Problematika kemiskinan yang berbasis pada aspek kultural maupun struktural inilah yang harus diselesaikan bersama, mengingat program penanggulangan kemiskinan yang dilakukan oleh Pemerintah sebenarnya sudah sedemikian banyak. Titik persoalannya memang pada tingkat akurasi penerima program dan kemauan dari si penerima program untuk tidak menggantungkan diri pada program-program tersebut.

Kemiskinan merupakan permasalahan klasik yang selalu muncul dalam kehidupan masyarakat sehingga eksistensinya membutuhkan mendapat perhatian serta penanganan yang serius. Kemiskinan tidak lagi dipahami hanya sebatas ketidakmampuan

17 Soetomo. Strategi-Strategi Pembangunan Masyarakat. (Yogyakarta: Pustaka Pelajar, 2006). 283.

18 Robert Chamber. Pembangunan Masyarakat Desa, Mulai Dari Belakang. (Jakarta: LP3ES, 1987). 145. 
ekonomi, tetapi juga kegagalan memenuhi hak-hak dasar dan perbedaan perlakuan bagi seseorang atau kelompok orang dalam menjalani kehidupan secara bermartabat. Hak-hak dasar yang diakui secara umum meliputi terpenuhinya kebutuhan pangan, kesehatan, pendidikan, pekerjaan, perumahan, air bersih, pertanahan, sumber daya alam, lingkungan hidup, rasa aman dari perlakuan atau ancaman tindak kekerasan dan hak berpartisipasi dalam kehidupan sosial politik. Esensi kemiskinan adalah menyangkut kondisi kekurangan dari sebuah tuntutan kehidupan yang paling minimum, khususnya dari aspek konsumsi dan pendapatan.

Pembahasan terhadap masalah kemiskinan tidak bisa dipisahkan dari pembahasan mengenai faktor-faktor penyebabnya, baik dalam konteks pendidikan, peluang pekerjaan, pengelolaan dan distribusi aset, aksesibilitas modal, bahkan mentalitas. Kemiskinan merupakan penyakit masyarakat yang terjadi di setiap negara, baik negara maju maupun negara berkembang, apalagi negara terbelakang. Adapun persebaran permasalahan kemiskinan tidak hanya berhenti di pedesaan, bahkan juga diperkotaan.

Secara konseptual dan praktis, kemiskinan dipengaruhi oleh berbagai faktor yang saling berkaitan, antara lain tingkat pendapatan masyarakat, pengangguran, kesehatan, pendidikan, akses terhadap barang dan jasa, lokasi, geografis, gender dan lokasi lingkungan. Pada konteks Indonesia, kemiskinan menjadi salah satu fokus perhatian para pendiri bangsa yang ditunjukkan dengan munculnya pengaturannya pada Pasal 134 Undang-undang Dasar Republik Indonesia Tahun 1945 yang menyatakan: Fakir miskin dan anak-anak yang terlantar dipelihara oleh Negara. Negara mengembangkan sistem jaminan sosial bagi seluruh rakyat dan memberdayakan masyarakat yang lemah dan tidak mampu sesuai dengan martabat kemanusiaan.

Pada konteks Indonesia, kemiskinan masih menjadi pekerjaan rumah yang terus melekat pada pemerintah. Hal ini karena angka kemiskinan di Indonesia masih relatif besar dari 
tahun ke tahun, di tengah upaya-upaya yang telah dan sedang dilakukan pemerintah untuk menanggulanginya. Berdasarkan rilis BPS, pada tahun 2010 angka kemiskinan yaitu 13,3\%, Tahun 2011 $(12,36 \%)$, tahun $2012(11,66 \%)$, tahun $2013(11,47 \%)$, tahun 2014 $(10,96 \%)$, tahun $2015(11,13 \%)$, tahun 2017 menjadi 10,12\%, tahun 2018 (9,84 \%). Terakhir pada tahun 2019 Badan Pusat Statistik (BPS) mencatat jumlah penduduk miskin di Indonesia pada Maret 2019 menjadi 25,144 juta orang atau berada di angka $9,41 \%$.

Data-data yang mengemuka terkait kemiskinan di atas yang memperlihatkan bahwa masalah kemiskinan masih menjadi permasalahan utama yang harus diselesaikan oleh bangsa Indonesia. Pemerintah memang sudah melakukan berbagai upaya untuk mengatasi kondisi kemiskinan yang ada. Berbagai penyusunan kebijakan dan langkah-langkah konkrit telah dilakukan, baik kebijakan untuk melakukan percepatan penanggulangan kemiskinan melalui penetapan program-program perlindungan sosial, maupun kebijakan untuk melakukan pendataan penduduk miskin. Kebijakan yang telah ditetapkan oleh pemerintah antra lain: Peraturan Presiden Nomor 166 Tahun 2014 tentang Percepatan Penanggulangan Kemiskinan. Pada Perpres tersebut Pemerintah menetapkan beberapa program perlindungan sosial seperti: Program Simpanan Keluarga Sejahtera; Program Indonesia Pintar serta Program Indonesia Sehat. Perpres tersebut juga mengamanatkan tentang perlunya pendataan penerima program perlindungan sosial. Melalui Peraturan Presiden Nomor 166 Tahun 2014 dijelaskan bahwa Program penanggulangan kemiskinan adalah kegiatan yang dilakukan oleh pemerintah, pemerintah daerah, dunia usaha, serta masyarakat untuk meningkatkan kesejahteraan masyarakat. Ketentuan tersebut menegaskan bahwa tanggung jawab untuk melakukan penanggulangan kemiskinan bukan hanya pada pemerintah pusat saja, namun memerlukan dukungan dan keikutsertaan pemerintah daerah maupun masyarakat luas dan dunia usaha. Dari sisi 
kelembagaan, Pemerintah juga sudah menaruh perhatian yaitu dengan dibentuknya Tim Nasional Percepatan Penanggulangan Kemiskinan yang dibentuk melalui Peraturan Presiden Nomor 15 Tahun 2010. Selain di tingkat Nasional, Peraturan Presiden Nomor 15 Tahun 2010 ini juga mengamanatkan pembentukan Tim Koordinasi Penanggulangan Kemiskinan Daerah.

Seperti halnya Indonesia, problem kemiskinan sampai hari ini juga masih menjadi pekerjaan rumah Provinsi Jambi. Berdasarkan data BPS Provinsi Jambi per Maret 2019, jumlah penduduk miskin di wilayah perkotaan masih di kisaran angka 10,41\%, sedangkan di pedesaan sejumlah 6,75\%. Artinya, para pemimpin yang lahir dari 'rahim' pilkada di Provinsi Jambi harus memiliki program-program yang diharapkan mampu mengatasi problem sosial klasik ini. Karena memang itulah tujuan utama dari diterapkannya pilkada di Indonesia dalam kerangka sistem desentralisasi.

Berdasarkan regional Pulau Sumatera, jumlah penduduk miskin di Provinsi Jambi berada pada posisi menengah jika dibandingkan dengan provinsi-provinsi lain di wilayah yang dulu juga dikenal sebagai Swarna Dwipa ini. Persentase penduduk miskin terbesar berada di Provinsi Aceh yaitu sebesar 15,32 persen, sementara persentase penduduk miskin terendah berada di Provinsi Bangka Belitung yaitu sebesar 4,62 persen. Dari sisi jumlah, sebagian besar penduduk miskin berada di Provinsi Sumatera Utara, Sumatera Selatan dan Lampung, sedangkan jumlah penduduk miskin terendah berada di Provinsi Bangka Belitung.

Kompleksnya permasalahan kemiskinan secara regional tersebut juga terjadi di Provinsi Jambi, yakni bukan saja pada aspek penyebabnya, namun yang tidak kalah memprihatinkan adalah pada aspek penanggulangannya yang sampai saat ini belum mampu menurunkan angka kemiskinan dan kesenjangan ekonomi secara signifikan. 
Berdasarkan data BPS dapat diketahui bahwa sejak 20152019 situasi kemiskinan di Provinsi Jambi mengalami fluktuasi dengan kecenderungan yang semakin membaik. Pada 2015, jumlah penduduk miskin tercatat sebanyak 301 ribu orang. Pada 2016, jumlah penduduk miskin tercatat sebanyak 290 ribu orang. Jumlah tersebut terus mengalami kecenderungan yang menurun meskipun berfluktuasi sejalan dengan dinamika tingkat kesejahteraan penduduk Provinsi Jambi. Pada tahun 2017, jumlah penduduk miskin Provinsi Jambi kembali mengalami penurunan menjadi 286 ribu orang dibandingkan tahun sebelumnya. Kemudian, pada 2018 jumlah penduduk miskin kembali menurun dalam kisaran 282 ribu orang. Sedangkan pada tahun terbaru (2019), angka kemiskinan di Provinsi Jambi kembali menurun menjadi 7,60 persen.

Di samping itu, tingkat kemiskinan Provinsi Jambi periode Maret 2010-Maret 2019 secara relatif mengalami penurunan kecuali pada periode September 2014-September 2015 mengalami kenaikan cukup signifikan. Sedangkan secara absolut selama periode Maret 2010-Maret 2019 mengalami kenaikan jumlah penduduk miskin dari 241,61 ribu orang pada Maret 2010 menjadi 274,32 ribu orang pada Maret 2019.

Terkait dengan mekanisme pengukuran tingkat kemiskinan sebuah wilayah digunakan Garis Kemiskinan (GK) sebagai indikatornya. GK merupakan batas minimum pengeluaran perkapita per bulan untuk memenuhi kebutuhan minimum makanan dan non makanan yang akan memisahkan seseorang tergolong miskin atau tidak. Garis Kemiskinan dipergunakan sebagai suatu batas untuk mengelompokkan penduduk menjadi miskin atau tidak miskin. Penduduk miskin adalah penduduk yang memiliki rata-rata pengeluaran per kapita per bulan di bawah Garis Kemiskinan. Selama periode September 2018-Maret 2019, Garis Kemiskinan naik sebesar 4,20 persen, yaitu dari Rp 430.435 per kapita per bulan pada September 2018 menjadi Rp 448.509 per kapita per bulan pada Maret 2019. Dengan memperhatikan komponen Garis Kemiskinan (GK) yang terdiri dari Garis 
Kemiskinan Makanan (GKM) dan Garis Kemiskinan Bukan Makanan (GKBM), terlihat bahwa peranan komoditi makanan masih jauh lebih besar dibandingkan peranan komoditi bukan makanan (perumahan, sandang, pendidikan, dan kesehatan). Besarnya sumbangan GKM terhadap GK pada Maret 2019 sebesar 76,65 persen. Pada Maret 2019, komoditi makanan yang memberikan sumbangan terbesar pada Garis Kemiskinan baik di perkotaan maupun di perdesaan pada umumnya sama, seperti beras yang memberi sumbangan sebesar 19,14 persen di perkotaan dan 25,87 persen di perdesaan. Rokok kretek filter memberikan sumbangan terbesar kedua kepada Garis Kemiskinan (15,41 persen di perkotaan dan 14,77 persen di perdesaan). Komoditi lainnya adalah daging ayam ras (5,01 persen di perkotaan dan 3,63 persen di perdesaan), telur ayam ras (4,80 persen di perkotaan dan 3,68 persen di perdesaan), gula pasir (2,74 persen di perkotaan dan 3,25 persen di perdesaan). Sedangkan komoditi bukan makanan yang memberikan sumbangan besar adalah perumahan, bensin, listrik, pendidikan, perlengkapan mandi dan pakaian jadi perempuan dewasa, hal ini terjadi baik di perkotaan maupun di perdesaan.

Komoditas yang memberi sumbangan besar terhadap garis kemiskinan masyarakat Provinsi Jambi baik daerah perkotaan maupun pedesaan (Maret 2019) adalah untuk kelompok makanan berupa beras (19,14 persen dan 25,87 persen), rokok kretek filter (15,41 persen dan 14,77 persen), sedangkan untuk kelompok bukan makanan yaitu perumahan (5,21 persen dan 5,34 persen), listrik (4,91 persen dan 4,60 persen) dan bensin (4,81 persen dan 3,45 persen).

Permasalahan kemiskinan bukan hanya sekadar berapa jumlah dan persentase penduduk miskin. Dimensi lain yang perlu diperhatikan adalah tingkat kedalaman dan keparahan dari tingkat kemiskinan. Selain harus mampu memperkecil jumlah penduduk miskin, kebijakan penanggulangan kemiskinan juga sekaligus harus bisa mengurangi tingkat kedalaman dan keparahan dari kemiskinan. Indikator yang digunakan untuk mengukur tingkat 
kedalaman kemiskinan adalah Indeks Kedalaman Kemiskinan atau Poverty Gap Index (P1) yang dirumuskan oleh Foster-Greer-Thorbec (FGT). P1 merupakan ukuran rata-rata kesenjangan pengeluaran masing-masing penduduk miskin terhadap garis kemiskinan, angka P1 yang semakin mendekati 0 menunjukkan rata-rata pengeluaran penduduk miskin semakin mendekati garis kemiskinan.

Penurunan nilai indeks ini mengindikasikan bahwa rata-rata pengeluaran penduduk miskin cenderung semakin mendekati Garis Kemiskinan. Apabila dibandingkan antara daerah perkotaan dan perdesaan, untuk P1 Provinsi Jambi selama periode tahun 2018-2018, maka daerah perkotaan memiliki nilai P1 selalu lebih besar dibandingkan daerah perdesaan. Sedangkan indikator yang digunakan untuk mengukur tingkat keparahan kemiskinan adalah Indeks Keparahan Kemiskinan atau Distributionally Sensitive Index (P2) yang dirumuskan oleh Foster - Greer - Thorbec (FGT). P2 memberikan gambaran penyebaran pengeluaran diantara penduduk miskin, angka P2 yang semakin mendekati 0 menunjukkan ketimpangan pengeluaran penduduk miskin secara umum semakin kecil. Pada periode Maret 2018-Maret 2019, Indeks Kedalaman Kemiskinan (P1) dan Indeks Keparahan Kemiskinan (P2) mengalami penurunan. Indeks Kedalaman Kemiskinan turun dari 1,302 pada Maret 2018 menjadi 1,228 pada Maret 2019. Demikian pula Indeks Keparahan Kemiskinan turun dari 0,322 (Maret 2018) menjadi 0,299 (Maret 2019). Penurunan nilai indeks ini mengindikasikan bahwa rata-rata pengeluaran penduduk miskin cenderung semakin mendekati Garis Kemiskinan dan ketimpangan pengeluaran penduduk miskin juga semakin mengecil. Apabila dibandingkan antara daerah perkotaan dan perdesaan, nilai Indeks Kedalaman Kemiskinan (P1) dan Indeks Keparahan Kemiskinan (P2) di daerah perdesaan lebih rendah dibandingkan dengan di perkotaan. Pada Maret 2019, nilai Indeks Kedalaman Kemiskinan (P1) untuk perkotaan sebesar 1,740, sementara di daerah perdesaan mencapai 0,981. Nilai Indeks Keparahan Kemiskinan 
(P2) untuk perkotaan sebesar 0,445 sementara di daerah perdesaan sebesar 0,229.

Bila dilihat per kabupaten/kota, Kabupaten Tanjung Jabung Timur, Kabupaten Tanjung Jabung Barat dan Kabupaten Batanghari selama tahun 2017 - 2018 terus memperlihatkan tingkat kemiskinan yang lebih tinggi dari Provinsi Jambi. Hal menarik terlihat pada Kabupaten Batanghari yang tingkat kemiskinannya tahun 2018 'hanya' menurun 0,10 persen dibandingkan tahun 2017, sementara Kabupaten Tanjung Jabung Timur menurun 0,20 persen dibandingkan tahun sebelumnya. Tingkat kemiskinan pada wilayah-wilayah ini berhubungan dengan kesejahteraan petani yang belum membaik akibat nilai tukar petani yang masih rendah.

Berdasarkan Berita Resmi yang diekspos BPS, persentase penduduk miskin di Provinsi Jambi dari tahun 2018 sampai tahun 2019 berfluktuatif. Bila dirata-rata pada rentang tersebut maka terjadi kenaikan 0,27 persen setiap tahunnya. Fakta lain adalah perbandingan persentase penduduk miskin antara daerah perkotaan dan perdesaan selama periode tahun 2018-2019 memperlihatkan bahwa persentase penduduk miskin di perkotaan lebih besar daripada perdesaan. Namun bila dilihat dari jumlah penduduk miskin, maka jumlah penduduk miskin di perdesaan lebih banyak dibandingkan di perkotaan. Hal ini disebabkan oleh jumlah penduduk yang hidup di perdesaan lebih banyak daripada penduduk yang tinggal di kota.

Melihat aspek kesejahteraan masyarakat tdak hanya terkait kemiskinan, tetapi juga dapat memerhatikan tingkat Indeks Pembangunan Manusia (IPM). Pembangunan manusia didefinisikan sebagai proses perluasan pilihan bagi penduduk (enlarging people choice). IPM merupakan indikator penting untuk mengukur keberhasilan dalam upaya membangun kualitas hidup manusia (masyarakat/penduduk). IPM menjelaskan bagaimana penduduk dapat mengakses hasil pembangunan dalam memperoleh pendapatan, kesehatan, pendidikan, dan sebagainya. IPM diperkenalkan oleh United Nations Development Programme 
(UNDP) pada tahun 1990 dan metode penghitungan direvisi pada tahun 2010.

IPM dibentuk oleh tiga dimensi dasar, yaitu umur panjang dan hidup sehat (a long and healthy life), pengetahuan (knowledge), dan standar hidup layak (decent standard of living). Umur panjang dan hidup sehat digambarkan oleh Umur Harapan Hidup saat lahir $(U H H)$ yaitu jumlah tahun yang diharapkan dapat dicapai oleh bayi yang baru lahir untuk hidup, dengan asumsi bahwa pola angka kematian menurut umur pada saat kelahiran sama sepanjang usia bayi. Pengetahuan diukur melalui indikator Rata-rata Lama Sekolah dan Harapan Lama Sekolah. Rata-rata Lama Sekolah (RLS) adalah rata-rata lamanya (tahun) penduduk usia 25 tahun ke atas yang telah atau sedang menjalani pendidikan formal. Harapan Lama Sekolah (HLS) didefinisikan sebagai lamanya (tahun) sekolah formal yang diharapkan akan dirasakan oleh anak pada umur tertentu di masa mendatang. Standar hidup yang layak digambarkan oleh pengeluaran per kapita disesuaikan, yang ditentukan dari nilai pengeluaran per kapita dan paritas daya beli (purchasing power parity). IPM dihitung berdasarkan rata-rata geometrik indeks kesehatan, indeks pengetahuan, dan indeks pengeluaran. Penghitungan ketiga indeks ini dilakukan dengan melakukan standardisasi dengan nilai minimum dan maksimum masing-masing komponen indeks.

IPM merupakan indikator yang digunakan untuk melihat perkembangan pembangunan dalam jangka panjang. Untuk melihat kemajuan pembangunan manusia, terdapat dua aspek yang perlu diperhatikan, yaitu kecepatan dan status pencapaian. Secara umum, pembangunan manusia Provinsi Jambi terus mengalami kemajuan selama periode 2010 hingga 2018. IPM Provinsi Jambi meningkat dari 65,39 pada tahun 2010 menjadi 70,65 pada tahun 2018. Selama periode tersebut, IPM Provinsi Jambi rata-rata tumbuh sebesar 0,97 persen per tahun. Pada periode 2017- 2018, IPM Provinsi Jambi tumbuh 0,94 persen. Pertumbuhan pada periode tersebut lebih tinggi apabila dibandingkan dengan kenaikan 
pada periode 2016-2017, yang tumbuh sebesar 0,53 persen. Kurun waktu 2010 hingga 2018 IPM Provinsi Jambi menunjukkan kemajuan yang besar. Dan pada tahun 2018, IPM Provinsi Jambi tembus di atas 70 poin yang berarti meningkat dari level "sedang"menjadi "tinggi” dibandingkan tahun sebelumnya. Hal ini menjadikan kebanggaan tersendiri dimana bisa dikatakan IPM Provinsi Jambi telah "naik kelas".

Pada tahun 2018, pencapaian pembangunan manusia di tingkat kabupaten/kota cukup bervariasi. IPM pada level kabupaten/kota berkisar antara 63,32 (Tanjung Jabung Timur) hingga 77,41 (Kota Jambi). Pada dimensi umur panjang dan hidup sehat, Umur Harapan Hidup saat lahir berkisar antara 65,86 tahun (Tanjung Jabung Timur) hingga 72,43 tahun (Kota Jambi). Sementara pada dimensi Pengetahuan, Harapan Lama Sekolah berkisar antara 11,85 tahun (Tanjung Jabung Timur) hingga 14,77 tahun (Kota Sungai Penuh); serta Rata-rata Lama Sekolah berkisar antara 6,34 tahun (Tanjung Jabung Timur) hingga 10,67 tahun (Kota Jambi). Sedangkan, pengeluaran per kapita disesuaikan di tingkat kabupaten/kota berkisar antara 8,46 juta rupiah per tahun (Muaro Jambi) hingga 11,91 juta rupiah per tahun (Kota Jambi).

Kemajuan pembangunan manusia terlihat dari perubahan status pembangunan manusia di tingkat kabupaten/kota. Sejak tahun 2015 tidak ada lagi kabupaten/kota yang berstatus "rendah" di mana sebelumnya masih terdapat 1 (satu) kabupaten dengan status tersebut. Satu-satunya kabupaten yang sebelumnya berstatus "rendah" tersebut adalah Kabupaten Tanjung Jabung Timur, dan telah beralih menjadi status "sedang" bersama 8 kabupaten lainnya. Sementara pembangunan manusia dengan status "tinggi" telah dicapai oleh Kota Jambi dan Kota Sungai Penuh sejak tahun 2010. Pada tahun 2017 bertambah Kabupaten Kerinci yang mengalami perubahan status dari level "sedang" menjadi "tinggi".

Peningkatan IPM di tingkat provinsi juga tercermin pada level kabupaten/kota. Selama periode 2017 hingga 2018, seluruh kabupaten/kota mengalami peningkatan IPM. Pada periode ini, 
tercatat tiga kabupaten dengan kemajuan pembangunan manusia paling cepat, yaitu Kabupaten Tanjung Jabung Barat (1,48 persen), Kota Sungai Penuh (1,25 persen) dan Kabupaten Tanjung Jabung Timur (1,13 persen). Sementara itu, kemajuan pembangunan manusia di Kabupaten Batang Hari (0,59 persen), Kabupaten Sarolangun ( 0,55 persen) dan Kabupaten Bungo (0,55 persen) tercatat paling lambat di Provinsi Jambi selama tahun 2017-2018.

\section{Kenapa Kemiskinan Masih Cukup Tinggi di Provinsi Jambi?}

Terkait mengemukanya problem kemiskinan di atas, maka perlu dicarikan akar masalahnya. Berdasarkan kajian terhadap data yang ada, salah satu faktor penyebabnya adalah kesenjangan wilayah berupa masih besarnya disparitas kontribusi PDRB antar Kabupaten/kota terhadap PDRB Provinsi Jambi. Kondisi tingkat kemiskinan dan pengangguran antar wilayah Kabupaten/kota di Provinsi Jambi juga menunjukkan disparitas yang cukup tinggi. Beberapa Kabupaten yang mempunyai share tinggi dalam pembentukan PDRB Provinsi Jambi mempunyai tingkat Kemiskinan dan pengangguran yang tinggi pula. Sampai saat ini Kabupaten/kota yang Tingkat Kemiskinannya masih di atas rata-rata Provinsi, yaitu Kabupaten Tanjung Jabung Timur, Tanjung Jabung Barat, Batanghari, Sarolangun dan Kota Jambi. Terdapat 5 Kabupaten/kota yang mempunyai Tingkat pengangguran Terbuka di atas rata-rata Provinsi, yaitu Kota Sungai Penuh, Kota Jambi, Kabupaten Merangin, dan Kabupaten Sarolangun. Hal ini tentunya harus ada upaya khusus untuk mendorong percepatan pengurangan kemiskinan dan pengangguran.

Salah satu ukuran ketimpangan yang sering digunakan adalah Gini Ratio. Nilai Gini Ratio berkisar antara 0-1. Semakin tinggi nilai Gini Ratio menunjukkan ketimpangan yang semakin tinggi. Koefisien Gini Provinsi Jambi berdasarkan daerah perkotaan dan perdesaan juga terlihat ketimpangan pendapatan. Secara nasional, Gini Ratio Jambi pada Maret 2010 tercatat sebesar 0,304 dan meningkat menjadi 0,359 pada September 2012. Gini Ratio turun pada September 2013 menjadi 0,327 dan naik terus hingga Maret 
2015 mencapai angka tertinggi yaitu sebesar 0,361. Pada September 2015 hingga Maret 2019 cenderung terjadi penurunan. Berdasarkan daerah tempat tinggal, Gini Ratio di daerah perkotaan pada Maret 2019 tercatat sebesar 0,351. Angka ini sama dengan Gini Ratio September 2018 yang sebesar 0,351. Untuk daerah perdesaan Gini Ratio Maret 2019 tercatat sebesar 0,287. Angka ini juga menurun sebesar 0,009 poin dibanding Gini Ratio September 2018 yang sebesar 0,295.

Hal menarik terjadi pada September 2011 dan Maret 2014 dimana tingkat ketimpangan di perkotaan lebih rendah daripada di perdesaan. Apabila dihubungkan dengan kemiskinan, memang pada periode tersebut penurunan kemiskinan di perkotaan lebih tinggi daripada di perdesaan, hal tersebut bisa menjadi dasar kenapa ketimpangan di perkotaan lebih rendah daripada perdesaan. Pada periode Maret 2012-September 2013, perbedaan ketimpangan antara perkotaan dan perdesaan begitu besar yang mencapai puncaknya pada September 2012. Hal ini bisa disebabkan karena terjadinya peningkatan persentase penduduk miskin di perkotaan yang merupakan tertinggi dalam periode itu, sementara di perdesaan terjadi penurunan persentase penduduk miskin. Ada beberapa kabupaten/kota yang tingkat ketimpangan pendapatannya cenderung naik yaitu Kabupaten Merangin, Tanjung Jabung Timur, dan Kota Sungai Penuh. Sementara itu untuk Kabupaten Bungo dan Tanjung Jabung Barat sangat berfluktuasi naik-turun.

Selain Gini Ratio ukuran ketimpangan lain yang sering digunakan adalah persentase pengeluaran pada kelompok penduduk 40 persen terbawah atau yang dikenal dengan ukuran ketimpangan Bank Dunia. Berdasarkan ukuran ini tingkat ketimpangan dibagi menjadi 3 kategori, yaitu tingkat Ketimpangan Tinggi jika persentase pengeluaran kelompok penduduk 40 persen terbawah angkanya dibawah 12 persen, Ketimpangan Sedang jika angkanya berkisar antara 12-17 persen, serta Ketimpangan Rendah jika angkanya berada diatas 17 persen. 
Pada Maret 2019, persentase pengeluaran pada kelompok 40 persen terbawah adalah sebesar 20,84 persen yang berarti Jambi berada pada kategori ketimpangan rendah. Persentase pengeluaran pada kelompok penduduk 40 persen terbawah pada bulan Maret 2019 ini meningkat jika dibandingkan dengan kondisi September 2018 yang sebesar 20,15 persen dan meningkat jika dibandingkan dengan kondisi Maret 2018 yang sebesar 20,08 persen.

Sejalan dengan informasi yang diperoleh dari Gini Ratio, ukuran ketimpangan Bank Dunia pun mencatat hal yang sama yaitu meskipun sama-sama tergolong ketimpangan rendah namun ketimpangan di perdesaan lebih baik dibandingkan dengan ketimpangan di perkotaan. Hal ini bisa dilihat dari persentase pengeluaran pada kelompok penduduk 40 persen terbawah di daerah perkotaan lebih rendah dibanding daerah perdesaan. Pada Maret 2019, di daerah perkotaan tercatat sebesar 19,04 persen, sedangkan di daerah perdesaan sebesar 22,43 persen. Melihat masih besarnya kemiskinan di Provinsi Jambi, maka kesenjangan pembangunan antar wilayah harus menjadi perhatian pemerintah.

Upaya membangun Provinsi Jambi tercantum dalam Visi besar berupa Jambi yang Tertib, Unggul, Nyaman, Tangguh, Adil dan Sejahtera (TUNTAS), yang tertuang dalam Rencana Pembangunan Jangka Menengah Daerah (RPJMD)-Perubahan Tahun 2016-2021. RPJMD-Perubahan ini memuat 6 misi yang akan dijalankan oleh Pemerintah Provinsi Jambi dalam upaya mewujudkan Visi Jambi TUNTAS tersebut. Terkait dengan pengentasan kemiskinan, terdapat 3 misi yang terhubung secara langsung, yaitu Misi 2: Meningkatkan kualitas sumber daya manusia yang sehat, terdidik, berbudaya, agamis, dan berkesetaraan gender, Misi 4: Meningkatkan daya saing daerah melalui optimalisasi pembangunan ekonomi kerakyatan yang didukung oleh penerapan Ilmu pengetahuan, teknologi, dan inovasi (IPTEKIN) berwawasan lingkungan, dan Misi 5: Meningkatkan aksebilitas dan kualitas infrastruktur umum, pengelolaan energi dan sumber daya alam yang berkeadilan dan berkelanjutan, serta Misi 6: Meningkatkan 
kualitas kehidupan masyarakat. Ketiga Misi Jambi TUNTAS ini menjadi acuan utama kebijakan-kebijakan pengentasan kemiskinan dalam lingkup Pemerintah Provinsi Jambi 2016-2021.

Berdasarkan beberapa kondisi perwilayahan, maka kebijakan pembangunan Provinsi Jambi difokuskan kepada upaya peningkatan kesejahteraan masyarakat dan merupakan turunan dari kebijakan pembangunan Nasional dengan mempertimbangkan keunggulan daerah dan kearifan lokal masyarakat Provinsi Jambi.

\section{Penutup}

Kemiskinan masih menjadi isu utama dalam pembangunan sosial ekonomi di Provinsi Jambi, terutama dalam 5 tahun terakhir pasca pemilihan gubernur 2015. Kemiskinan merupakan permasalahan masyarakat Provinsi Jambi yang mendesak dan memerlukan langkah-langkah penanganan dan pendekatan yang sistematik, terpadu dan menyeluruh untuk mengurangi beban masyarakat miskin dan memenuhi hak-hak dasar warga negara secara layak. Dalam rangka peningkatan dan percepatan upaya penanggulangan kemiskinan diperlukan upaya penajaman yang meliputi sasaran, perencanaan dan keterpaduan program antar bidang terkait.

Oleh karena kemiskinan tidak hanya terkait ekonomi, maka penanganan yang komprehensif melibatkan berbagai bidang harus dilakukan, di samping koordinasi di setiap level pemerintahan (pusat, provinsi dan kabupaten/kota). Selain itu, percepatan penanggulangan kemiskinan juga perlu didukung oleh upaya penciptaan tata pemerintahan yang baik, yaitu sebuah tata pemerintahan yang mengedepankan hubungan sinergitas antara elemen-elemen pemerintah, swasta dan masyarakat yang mendasarkan prinsip-prinsip partisipasi, akuntabilitas, transparansi dan pada pengutamaan kepentingan masyarakat.

Harapannya, korelasi yang kuat secara konseptual antara pemilihan umum dan kesejahteraan masyarakat di era otonomi daerah akan benar-benar terwujud dalam implementasinya. 
Kesejahteraan masyarakat sebagai outcome dari seluruh proses politik di era pasca reformasi menjadi sebuah keniscayaan. Ini semua akan terjadi jika pemerintah yang lahir dari proses-proses Pilkada menghasilkan kebijakan-kebijakan yang memerhatikan kebutuhan-kebututuhan masyarakat daerah, termasuk di Provinsi Jambi. Jika tidak, maka problem-problem seperti kemiskinan yang telah ada di era sebelumnya akan terus diwarisi untuk masa-masa mendatang.

\section{Daftar Pustaka}

Badan Pusat Statistik (BPS). Provinsi Jambi Dalam Angka 2019. Kota Jambi: Author, 2019.

Bird, R., \& Vaillancourt, F. Fiscal Decentralization in Developing Countries. United Kingdom: Cambridge University Press, 1998.

Brillo, B. B. C. 'The politics of lake governance: Sampaloc Lake, Pandin Lake, and Tadlac Lake of the Laguna de Bay Region, Philippines'. Asia-Pacific Social Science Review (2017) 17(1): 6679.

Retrieved from https://papers.ssrn.com/sol3/papers.cfm?abstract id=2979 $\underline{439}$.

Chamber, Robert. Pembangunan Masyarakat Desa, Mulai Dari Belakang. Jakarta: LP3ES, 1987.

Halim, Abdul. Politik Lokal: Pola, Aktor, dan Alur Dramatikalnya. Yogyakarta: Lembaga Pengkajian Pembangunan Bangsa (LP2B), 2014.

Hidayatullah, Indra. 'Peran pemerintah di bidang perekonomian dalam Islam'. DINAR, Vol. 1 No. 2 Januari 2015. Retrieved from journal.trunojoyo.ac.id $>$ dinar $>$ article $>$ download.

HM, Pahrudin. 'The role of the Merangin regency government through welfare policy in the globalization era'. The Journal of Society and Media 2019, Vol. 3(2) 216-236. DOI:10.26740/jsm.v3n2.p216-236.

HM, Pahrudin. Globalisasi dan Kebijakan Publik: Kajian Seputar Peranan Pemerintah Mewnjudkan Kesejabteraan di Tengah Dunia Tak Bersekat. Jakarta: Kencana Prenada Media Group, 2020. 
Kesuma, Arsyad Sobby. 'Islam dan politik pemerintahan (pemikiran politik Muhammad Husein Haikal)'. Analisis, Volume XIII, Nomor 2, Desember 2013. Retrieved from https://media.neliti.com/media/publications/57574-IDislam-dan-politik-pemerintahan-pemikiran.pdf.

Kisman, Z. A. and Tasar, I. 'The key element of local development' Procedia Economics and Finance, 15, pp. 16891696, 2014. https://doi.org/10.1016/S2212-5671(14)00642X.

Nak-ai, W. etc. 'Community public policy process for solving cadmium contamination problems in the environment: a case study of Mae Sod District, Tak Province. Kasetsart Journal of Social Sciences 39 (2018) 59-66. https://doi.org/10.1016/j.kjss.2017.11.006.

Nawawi, Ismail. Ekonomi Islam; Persepektif Konsep, Model, Paradigma,Teori dan Aspek. Hukum, Surabaya: Vira Jaya Multi Press, 2008.

Nugroho, Riant. Public Policy: Dinamika Kebijakan Publik, Analisis Kebijakan Publik, dan Manajemen Politik Kebijakan Publik. Jakarta: PT. Elex Media Komputindo, 2018.

Sharma, C. K. 'Reimagining federalism in india: exploring the frontiers of collaborative federal architecture. Asia-Pacific Social Science Review 15 (1) 2015, pp. 1-25. Retrieved from http://apssr.com/volume-15-no-1/reimagining-federalismin-india-exploring-the-frontiers-of-collaborative-federalarchitecture/.

Stoker, Gerry. The Politics of Local Government. London: The Macmillan Press Ltd, 1991.

Suyanto, Bagong. Perangkap Kemiskinan, Problem dan Strategi Pengentasannya dalam Pembangunan Desa. Yogyakarta: Aditya Media, 1996.

Suharto, Edi. Membangun Masyarakat Memberdayakan Rakyat. Bandung: PT. Refika Aditama, 2010.

Soetomo. Strategi-Strategi Pembangunan Masyarakat. Yogyakarta: Pustaka Pelajar, 2006.

Wikowski, J. and Kiba-Janiak, M. 'The role of local governments inthe development city logistics' Procedia-Social and Behavioral Sciences, $125, \quad$ p. 2014. https://doi.org/10.1016/j.sbspro.2014.01.1481. 